\title{
Review of All This Can Happen, by Siobhan Davies and David Hinton
}

Sanjoy Roy, Guardian

Keywords: narrative, composition, montage, connotation, adaptation

\section{Ed. note: This review is a reprint, originally published in Aesthetica Magazine on November 5, $2013 .{ }^{1}$}

All This Can Happen, a 50-minute film by David Hinton and choreographer Siobhan Davies, opens with images of men who cannot walk. One lies immobile in a hospital bed, his head trembling, eyes vacant with torment. Another, also institutionalised, tries to walk but fails. He falls, scrambles, and falls again, his whole body stiff with malfunction.

All this did happen. Every frame of this remarkable film comes from old, mostly black and white archive footage, complete with scratches and fingerprints. It is neither documentary nor constructed reality, but rather a wholly unexpected film adaptation of a short story by Swiss writer Robert Walser (1878-1956), about a man going for a walk.

The story, to which those opening images serve as a prologue, recounts the sights, sounds, encounters, and musings of a day's meandering: children playing in a school, a visit to the tax office, a display of women's hats, a stroll through a forest, an argument with a tailor. Lovingly voiced by John Heffernan, the narration treats each moment, each thought and perception, with equal consideration, whether it is a gripe about automobiles, a memory of unbearable anguish, the sound of sublime music, or a chat with a dog. "The highest and the lowest, the most serious and the most hilarious things," he explains, "are to the walker equally beloved, beautiful, and valuable."

The footage often illustrates the story very directly, showing manual labourers on scaffolding when the narrator mentions workers, bookshelves for a bookshop, a spinning globe for the world. Yet the images constantly surprise us, and not only because of the non-sequiturs in the story as it wanders from street to restaurant to office, from anecdote to reflection to remembrance. Sometimes it is simply the strangeness of the scene: boys imitating birdsong; tiny books with minuscule print; a screenful of blinking eyes; a giant man, towering above everyone else. Sometimes it is 
the potency of the association: birds caught in the hand flying off into bushes, buds opening slowly, like blooms of arousal. Sometimes it is the unflinching simplicity of the image itself: the shock of a child being beaten, the natural beauty of fern fronds, the matter-of-factness of a man milking a cow, all accompanied by the unobtrusive marvels of Chu-Li Shewring's soundtrack.

But always it is because of a startling disjunction: the narration establishes a supple continuity, yet though the imagery follows the story devotedly, it has no continuity. It leaps between locations, splices scenes, switches subjects, and roams freely between poetic and literal modes, between the fantastic, the scientific, the surreal, and the mundane. It seems able to let the whole world in, and still stay true to a singular storyline. The imagery is discontinuous in other senses too. The screen is often split into multiple frames so that we notice how highly composed the film is. The frames themselves often freeze fleetingly, arresting the flow of time. Such stops literally give us pause; they let us take a moment. In fact, the whole film could be seen as the encounter between continuity-the story, the voice, time itself-and composition, or indeed choreography: the framing of action, the placement of sound, the arrangement of subjects and space.

But the reason to watch this film is not because it is artful and thoughtful, though it is that. It is because it restores us to our senses, because it touches-gently-both body and soul. To walk, it suggests, is to be in the world. A world that is physical, full of texture and sound and sensation; that is abstract, a matrix of space and time; that is imaginary, teeming with fantasies and terrors, desires, hopes and regrets; that is social, marked by encounters, engagements, negotiations; a world that is human. As a walk of life, All This Can Happen is, quite naturally, also shadowed by death, by not-walking, by not moving in space and time. "Where would I be," asks the walker, "if I was not here? Here, I have everything. And elsewhere, I would have nothing." ${ }^{3}$ All this it finds equally beloved, beautiful, and valuable.

\section{Biography}

Sanjoy Roy is a dance writer and reviewer, who has been writing for the Guardian since 2002. From 1989-2000 he was publications editor and designer for Dance Books Ltd, where he was also co-editor of the magazine Dance Now. He has contributed to many other publications, including the New Statesman, Dance Gazette, Dancing Times, Pulse, and Dance International. He is author of the popular Step by Step Guides to Dance (2008-11), a series of 59 accessible and informative profiles of choreographers and 
companies, published in the Guardian online. He maintains an archive of his published writing at http://www.sanjoyroy.net.

Email: sanjoy@sanjoyroy.net

\section{Notes}

${ }^{1}$ Roy, "Review of All This Can Happen."

${ }^{2}$ Davies and Hinton, All This Can Happen, 36:35.

${ }^{3}$ Ibid., 43:08.

\section{References}

All This Can Happen. Dir. Siobhan Davies and David Hinton. UK, 2012. Digital Video. Roy, Sanjoy. "Review of All This Can Happen, by Siobhan Davies and David Hinton." Aesthetica Magazine. Posted 5 November 2013.

http://www.aestheticamagazine.com/review-of-all-this-can-happen-by-siobhandavies-and-david-hinton/ 